\title{
Analysis of underground river network connectivity in Barat Cave, Karst Karangbolong, Central Java, using the Artificial Tracer Test Method
}

\author{
Alpine Prima Priambada ${ }^{1,2^{*}}$, Tjahyo Nugroho Adji ${ }^{1,2}$, Eko Haryono ${ }^{1,2}$, Romza Fauzan Agniy ${ }^{1}$, Ahmad Cahyadi ${ }^{1,2}$, \\ Muhammad Qodri Al-Ghozali ${ }^{1,2}$, Aulia Ika Rahmawati, ${ }^{1,2}$, Danung Shodikh Makhrizal ${ }^{1,2}$, Rakhmat Dwi Putra ${ }^{3}$, Danang \\ Riza Fauzi ${ }^{1,2}$, Elisabeth Supi Astuti ${ }^{1,2}$, Andy Setyawan ${ }^{1,2}$, Gangsar Edi Laksono ${ }^{1}$, Muslih Biladi ${ }^{3}$, Faizal Musthofa ${ }^{3}$ \\ ${ }^{1}$ Karst Research Group, Faculty of Geography, Universitas Gadjah Mada, Indonesia \\ ${ }^{2}$ Department of Environmental Geography, Faculty of Geography, Gadjah Mada University, Indonesia \\ ${ }^{3}$ Department of Geographic Information Science, Faculty of Geography, Universitas Gadjah Mada
}

\begin{abstract}
The connectivity of the Barat Cave underground river system needs to be known to support the implementation of proper environmental management so that water resources can be maintained sustainably. However, the mapping of underground river paths is often hindered by conditions of narrow cave passages, a barrier blocking the flow of water (siphon), deep underground lakes, underground waterfalls, as well as paths filled with water. This research was conducted in Barat Cave, Karangbolong Karst Area. The purpose of this study is to determine the upstream-downstream connectivity system in this underground river and define the characteristics of the passageway based on quantitative analysis of the transport parameters from the tracer test results. This underground river network analysis needs to be done because previous research has never analyzed this underground river network. The research method used in this study is divided into three stages, namely the pre-field stage, the field stage, and the post-field stage. The pre-field step includes determining the location of the study, collecting secondary data, and studying the literature. The field stage consists of a hydrogeological survey to find information on the presence of caves, springs, sinking stream ponors, or luweng in the study area, instantaneous discharge measurements, and tracer tests. The post-field stage includes data processing and analysis. The results showed that the Barat underground river system originated from the Kalimas sinking stream, Mblabak Cave, Pendok Cave, and Pagilangan sinking streams, then merged into a single tunnel without a flow breaker to the Barat Cave, Pengantin Cave, and appeared in the Kalikarak springs to become a surface river, with a tunnel pattern in the form of curvilinear branchwork. The transport parameters for the underground system tracing of the Barat cave have an advection value of $86.528 \mathrm{~m} /$ hour, a dispersion of $0.092 \mathrm{~m}^{2} /$ second, a dispersivity of 3.38 meters, and a recovery of $63 \%$. The transport value of the tracing test parameter is influenced by the characteristics of the passageway and underground river flow conditions.
\end{abstract}

\section{Introduction}

Karst is a landscape that has hydrological and geomorphological systems with its characteristics. Karst is a term used to describe a unique landscape with caves and underground water systems that develop and are formed as a result of the dissolving process in soluble rocks [1], such as limestone, dolomite, gypsum, halite, and conglomerates [2]. Water and its involvement in the dissolution process are the most important factors in forming karst landscapes [3].

One of the unique characteristics of hydrological conditions in karst areas is the scarcity or absence of surface drainage/rivers [4]. This occurs because the surface flow is lost through the sinkhole, which then becomes an underground flow that flows through the conduit voids that are formed in the karst rock. Karst surface water that is swallowed and enters through the ponor in the valley/doline includes a conduit passageway and can develop as open channels or vadose pipes [4]. Conduit tunnels that flow with water will comprise an underground river. This condition causes the karst aquifer to have heterogeneous-anisotropic properties; that is, its hydraulic conductivity varies widely, and its magnitude is controlled by the direction or size of secondary porosity or developing voids [5].

The formation of underground rivers is inseparable from the appearance of karst caves [6]. A cave is a naturally occurring underground cavity large enough for humans to enter, in which it can be fully or partially filled with sediment or water [7]. A cave is a naturally occurring cavity in rock that acts as a channel for water flow between the entry point (river flow) and the outlet point (spring or seepage) [8]. Caves connected will form a river system, and when the caves are flowed by water, an underground river is formed [9].*

\footnotetext{
${ }^{*}$ Corresponding author:

alpine.prima.priambada@mail.ugm.ac.id
} 
Underground river channel formed due to the dissolution process. Water that passes through underground rivers will come out as karst springs, but this water can also go directly into the sea. The search for underground rivers is often hindered by several conditions such as narrow passageways, a reduction in the dimensions of the passageway accompanied by a barrier obstructing the flow of water (siphon), deep underground lakes, underground waterfalls, passages full of water. To overcome this problem, artificial tracer tests can be used to map underground river connectivity.

Tracer test is a method used to define underground river connectivity $[6,10,11,1213]$. The analysis of the connectivity of the cave passage can be modelled by interpreting the breakthrough curve (BTC) of the tracer recorded by the fluorometer sensor, which is used to capture the tracer concentration.

This research was conducted in the underground river of Barat Cave, Karangbolong Karst Area, Kebumen Regency (Fig. 1). Geologically, this cave is located in the Kalipucang Formation, which is composed of shale, limestone, and limestone sandstones, with polymic breccias as inserts. The upper part of this formation consists of coral limestone with carbonate content reaching $95.5 \%$ to $99 \%$ to be classified as pure limestone [14-16]. This formation is Middle Miocene aged and deposited in an open shallow marine environment.

The underground river Barat Cave has an important value for the surrounding community in meeting water needs for bathing, washing and consumption, and supporting economic activities in the tourism sector. The water that flows in this underground river is used as a source of daily water. Therefore, this underground river system needs to be studied further so that proper environmental management can be applied to maintain its water resources sustainably. This research aims to define the underground river system of Barat Cave and to know the characteristics of the passageway based on the quantitative analysis of the transport parameters from the tracer test results. By knowing underground rivers and the attributes of their passages, proper environmental management can be implemented so that water resources can be preserved.

\section{Research Method}

The implementation of this research is divided into three stages, namely the pre-field stage, the field stage and the post-field stage. The pre-field step includes literature studies, determining the location of the study, and collecting secondary data. The determination of the study location takes into account the importance of underground rivers, the presence of annual (perennial) flows with large discharge, and accessibility to the site. These considerations underlie the choice of the Barat underground river as the object of research. Secondary data collected includes morphological data in the form of DEM (Digital Elevation Model) from Alos Palsar and hydrogeological data, which provides for mapping data from caves, springs, ponors, luweng, or existing connectivity routes between caves.

The field stage is more emphasized on obtaining primary data. Primary data collection is divided into field surveys to determine the presence of caves, springs, sinking streams, luweng and ponor in the study area, discharge measurements at monitoring points, and tracing tests on underground river flows. Discharge data, target peak concentration, and horizontal distance between the injection point and the point of observation are used in calculating the quantity of tracer poured, according to the formula [17]:

$$
M=1,9 \cdot 10^{-5}(L Q C)^{0,95}
$$

where:

$\mathrm{M}=$ quantity of tracer substance required $(\mathrm{kg})$;

$\mathrm{L}=$ the distance from the injection point to the observation point $(\mathrm{km})$;

$\mathrm{Q}=\operatorname{discharge}(\mathrm{L} / \mathrm{s})$;

$\mathrm{C}=$ peak concentration target $(\mu \mathrm{g} / \mathrm{L})$

Tracing tests were carried out using fluorescent dyes, namely uranine and tinopal, while the instrument used to record the tracer concentration was a fluorometer. The use of fluorescent dyes as tracing agents is based on their conservative nature, safety, low cost, and high detectability [17]. The properties of the tracer used are presented in Table 1.

Table 1. Properties of tracer uranine and tinopal

\begin{tabular}{|c|c|c|c|c|}
\hline No & Tracer & $\begin{array}{c}\text { Limit of } \\
\text { detection }\end{array}$ & Safety & Weaknesses \\
\hline 1 & Uranine & $\begin{array}{c}10^{-3} \\
(\mu \mathrm{g} / \mathrm{L})\end{array}$ & Safe & $\begin{array}{c}\text { absorbs at } \\
\text { low } \mathrm{pH}\end{array}$ \\
\hline 2 & Tinopal & $\begin{array}{c}10^{-3} \\
(\mu \mathrm{g} / \mathrm{L})\end{array}$ & Safe & $\begin{array}{c}\text { easily } \\
\text { absorbed }\end{array}$ \\
\hline
\end{tabular}

After conducting a survey of caves, springs, sinking streams, luweng, and ponor around the study area, the injection point is determined. The injection point is determined by considering the direction of water flow and the slope of the rock formation. Another factor that is taken into consideration is the direction and pattern of valley alignment at the study location. The injection points that are used as locations for tracer substances pouring include the Pagilangan sinking stream (IP1), the Kalimas sinking stream (IP2), and the Mblabak Cave (IP3). Tracer injection was performed at three different times. The I1 injection was carried out on October 10 2020, using uranine, the I2 injection was carried out on October 13 2020, using the tinopal substance, and the I3 injection was carried out on October 162020 , using the tinopal substance. FL30 fluorometer was installed in the Barat Cave (O.P.) from October 132020 to October 16 2020 , to record tracer substances poured in IP1 and IP2. Meanwhile, tracing agents from IP3 were captured using active charcoal. 


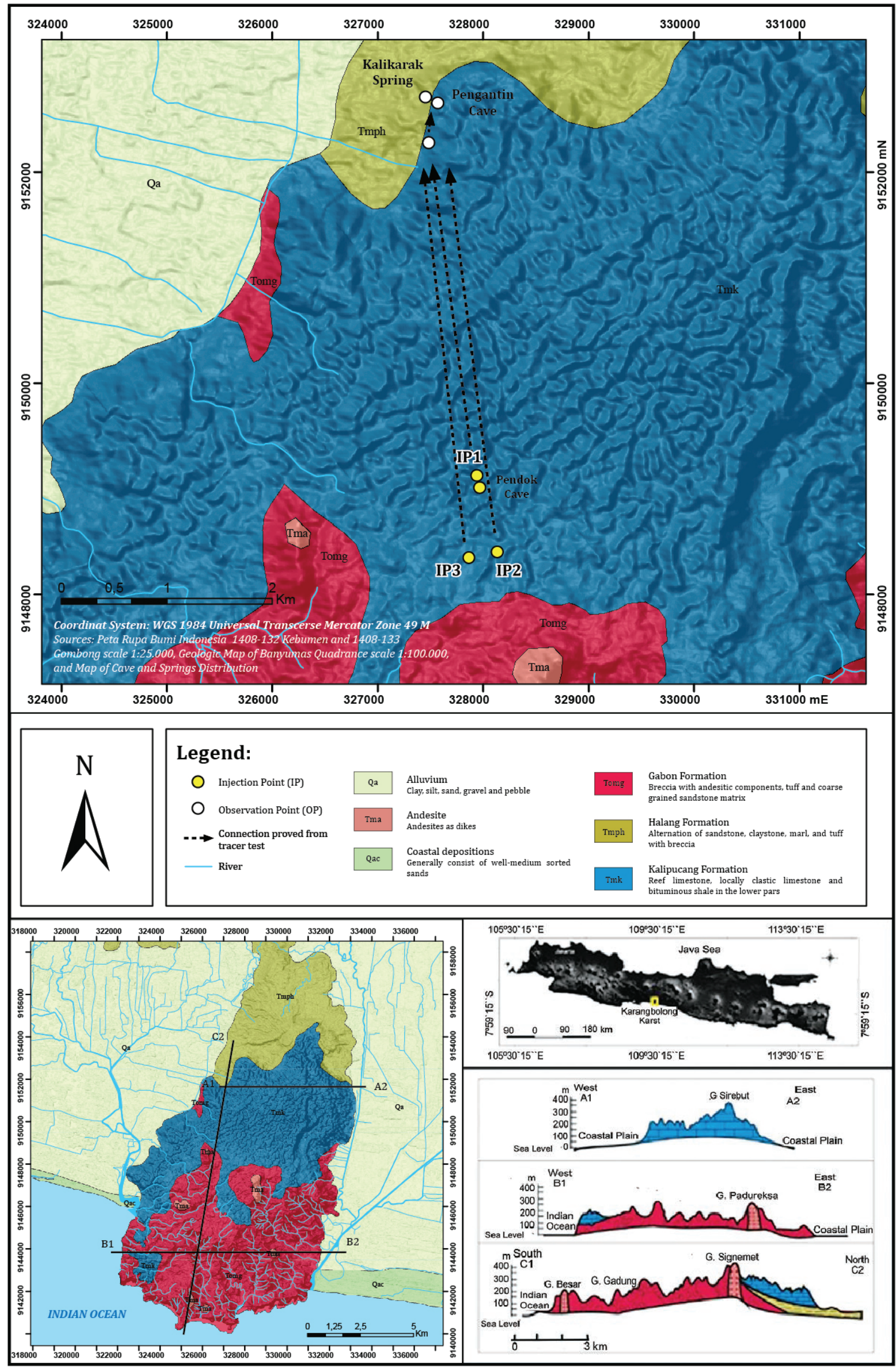

Fig. 1. Location of injection points, monitoring points, prediction of flow direction, and geological conditions of the study area. The geological condition of the study area shows the slope of the Kalipucang Formation to the north in the cross-section of C1-C2 [21] 
The post-field stage includes the processing and analysis of data obtained from field surveys and measurement results. Tracing test results are processed using Qtracer2 software. Qtracer2 is a software that is easy to use for tracing analysis in karst areas or other areas [18]. This Qtracer2 software processes tracing test data using the Advection-Dispersion Model to find the value of the transport parameter from the tracing test results.

Tracing test results analysis uses quantitative analysis, which emphasizes the interpretation of the transport parameters, including advection, dispersion, dispersivity, and recovery. This quantitative analysis is based on a detailed study of the breakthrough curve (BTC) resulting from the tracer recorded [19]. Meanwhile, there are parameters obtained from the analysis on the BTC, namely the time it was detected for the first time, the peak time, the maximum concentration, and the peak velocity.

The general equation regarding advection-dispersion is shown in the following equation [17]:

$$
\begin{array}{ll}
\frac{\partial c}{\partial t}=D_{l} \frac{\partial^{2} c}{\partial x^{2}}-v \frac{\partial c}{\partial x} \\
\text { where : } \\
\begin{array}{ll}
\mathrm{c} & =\text { concentration } \\
\mathrm{t} & =\text { time } \\
\mathrm{D}_{1} & =\text { dispersion longitudinal coefficient } \\
\mathrm{V} & =\text { flow velocity } \\
\mathrm{x} & =\text { longitudinal distance }
\end{array}
\end{array}
$$

The equation for calculating recovery is shown in the following equation [20]:

$$
\mathrm{R}_{\mathrm{m}}=\frac{M \text { out }}{M \text { in }}=\frac{\int_{t=0}^{t n}(C(t) \cdot Q(t)) d t}{M \text { in }} \times 100 \%
$$

where :

$$
\begin{array}{ll}
\mathrm{M}_{\text {in }} & =\text { amount of the trace substance in IP } \\
M_{\text {out }} & =\text { amount of the trace substance in IP } \\
t_{0} & =\text { initial detection time } \\
t_{n} & =\text { the end time of detection } \\
\mathrm{Q}(\mathrm{t}) & =\text { discharge in time- } \mathrm{t} \\
\mathrm{C}(\mathrm{t}) & =\text { concentration of the tracer in time- } \mathrm{t}
\end{array}
$$

\section{Results and Discussion}

The underground river connectivity of Barat Cave is defined by tracing tests. The discharge measurement was carried out at the OP before carrying out the tracing test, namely on October 9, 2020. The measured discharge of $751 /$ second was then used to determine the quantity of the tracer to be poured. Tracer injection was carried out at IP1, IP2, and IP3. IP1 and IP2 are sinking streams located in the transitional area between the Gabon Formation and the Kalipucang Formation, while IP3 is a cave that acts as a flow entry during the rainy season. The three injection points show the direction of flow north to the West Cave (OP) and the slope of the Kalipucang Formation, which slopes to the north (Fig. 1).

Meanwhile, the parallel valleys in the northwestern part of the Karangbolong Karst Area, which is around the study site, have a northwestward direction [21]. The direction of the parallel valley leads to the Barat Cave. Tracing test results prove that the three injection points have connectivity with the Barat Cave. Table 2 shows the characteristics of the tracing test in the Barat Cave underground river system.

The tracing test results curve analysis is then carried out by looking at the breakthrough curve (BTC) formed from the IP1 and IP2 tracing tests. The IP3 tracing test could not be analyzed because the tracer was recorded using charcoal. The shape of the breakthrough curve (BTC) resulting from the tracing test is influenced by the tracer character, flow conditions, and the structure of the aquifer [22]. That way, the void branching analysis can be conducted by looking at the peak of the breakthrough curve (BTC) tracing results. The tracing test results produce a breakthrough curve (BTC) with one peak, which means that the injection point and the observation point are connected through a single conduit void without any flow breakers. Breakthrough curve (BTC) tracing test results in IP1 and IP2 are shown in Fig. 2.

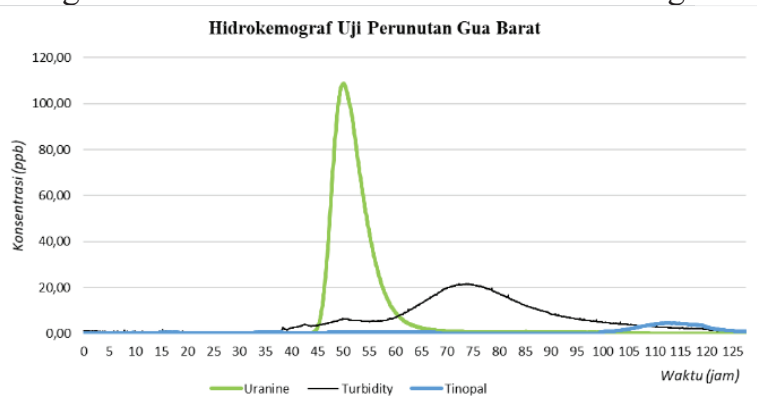

Fig. 2. Breakthrough curve (BTC) tracing test results in IP1 and IP2, which are monitored at the OP.

The underground river flow that passes through the Barat Cave has a direction towards Pengantin then exits through a single outlet at Kalikarak Springs, which then becomes a surface river. The appearance of uranine in Kalikarak Spring is presented in Fig. 3. Thus, the underground river connectivity system in the Barat Cave has a curvilinear branchwork void pattern. The curvilinear void pattern consists of several voids as tributaries that merge into a single, larger tunnel downstream [23]. In general, each primary water source such as doline or ponor contributes to one conduit channel, although more than one water input can supply one channel so that the curvilinear passageway resembles a dendritic surface river flow pattern $[23,24]$.

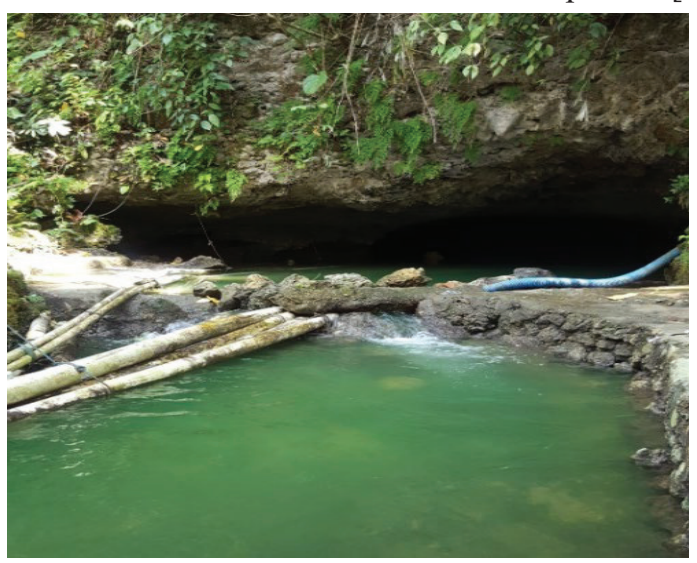

Fig. 3. The appearance of uranine in Kalikarak Springs 
Table 2. Parameters of tracing test results in the Barat Cave underground river system

\begin{tabular}{|c|c|c|c|c|}
\hline \multicolumn{2}{|c|}{ Time of injection } & 10/10/2020 14:35:00 WIB & 13/10/2020 14:00:00 WIB & 16/10/2020 15:45:00 WIB \\
\hline \multicolumn{2}{|c|}{ Injection points } & IP1 & IP2 & IP3 \\
\hline \multicolumn{2}{|c|}{ Observation points } & \multicolumn{3}{|c|}{$\mathrm{OP}$} \\
\hline \multicolumn{2}{|c|}{ Quantity (gr) } & 300 gram (uranine) & 110 gram (tinopal) & 100 gram (tinopal) \\
\hline \multicolumn{2}{|c|}{ Fluorometer type } & FL 30 & FL 30 & Charcoal \\
\hline \multicolumn{2}{|c|}{ Peak target of concentration } & $110 \mathrm{ppb}$ & $35 \mathrm{ppb}$ & \\
\hline Parameter & Unit & \multicolumn{3}{|c|}{ Value } \\
\hline First time of detection & $\min$ & 2840 & & \\
\hline Time to peak & $\min$ & 3145 & 2595 & \\
\hline $\begin{array}{l}\text { Maximum } \\
\text { concentration }\end{array}$ & ppb & 108 & 4.51 & \\
\hline Distance & meter & 3150 & 4030 & 3845 \\
\hline Peak velocity & $\mathrm{m} / \mathrm{min}$ & 1.00 & & \\
\hline \multicolumn{5}{|l|}{ ADM } \\
\hline Dispersion & $\mathrm{m}^{2} / \mathrm{sec}$ & 0.091988 & & \\
\hline Dispersivity & meter & 3.8272 & & \\
\hline Recovery & $\%$ & 63 & & \\
\hline Advection & $\mathrm{m} /$ hour & 87 & & \\
\hline $\mathrm{R}^{2}$ & - & 0.9834 & & \\
\hline
\end{tabular}

The breakthrough curve (BTC) characteristic shows a significant increase in tracer concentration to reach the peak concentration. The time needed to achieve the peak concentration from the first time it was detected 305 minutes. Meanwhile, the characteristics of the recession show a significant decline but experience a late slowdown or retardation. Retardation can be characterized by a breakthrough curve (BTC) that experiences tailings. This condition is indicated by the length of time it takes to reach a concentration of $0 \mathrm{ppb}$ from the peak concentration, which is 1210 minutes, but it is driven by rain events which are indicated by an increase in turbidity.

Retardation indicates that some tracer particles have a longer residence time in the flow, probably due to the flow through the underground lake causing flow retardation [25]. This condition causes some of the tracer dissolved substances to separate from the others due to the duality of flow, namely turbulent flow due to water hitting the passage walls or obstructions so that a slowed flow is formed and the main flow has a higher speed. Besides, retardation is also caused by the process of entering the water in IP1 into the underground river through two different ways, namely infiltration and entering through small cracks along with the flow.

The results of the tracing test on IP1 were processed using the Advection-Dispersion Model (ADM) using Qtracer2 software. The processing results show that the underground river Barat Cave has an advection value of $86.53 \mathrm{~m} /$ hour. The advection value reflects the horizontal displacement movement so that the higher the advection value, the faster the flow of flow from the injection point to the monitoring point and vice versa. Conduit development conditions influence advection value. Flow-through large conduits or underground lakes can cause a decrease in flow velocity as a result of an increase in a cross-sectional area [26]. This fact is in accordance with the flow rate equation $(\mathrm{Q}=\mathrm{V} \times \mathrm{A})$; when the cross-sectional area is larger, the flow velocity is getting smaller. Apart from that, the hydraulic gradient also affects the advection value [26]. The underground river Barat Cave has a hydraulic gradient value of 0.08 when calculated from IP1 to OP. The higher the hydraulic gradient value, the faster the advection value tends to be. In addition, this condition is also influenced by the conditions of the underground river passage.

The results of Qtracer2 software processing show a dispersion value of $0.091988 \mathrm{~m}^{2} /$ second or equivalent to $331.16 \mathrm{~m}^{2} /$ hour and a dispersivity value of $3.8272 \mathrm{~m}$. The dispersion value represents the tracer's spread over the flow per unit time, while the dispersivity represents the tracer's deviation from the waterway carrying it. The dispersion and dispersivity values are influenced by the characteristics of the conduit passageway and the flow conditions so that these two values can provide a general description of the flow tunnel conditions.

The dispersion and dispersivity values will increase more if there is considerable heterogeneity [25]. Heterogeneity is the variation in conduit geometry, including the presence of underground ponds or lakes, obstructions, underground waterfalls, or whirlpools that cause variations in flow velocity [27]. More specifically, the geometric irregularity/shape of the conduit is the variation in the size of the aisle, the winding passageway, and the hall with a pipe or siphon-like form [25]. The siphon/sump is part of the cave's passage, which was flooded [28]. A cave passage is called a 
siphon when there is a reduction in the hallway's dimensions accompanied by a barrier blocking water flow.

The occurrence of a conduit that has an irregular geometry will increase the dispersion value, which is triggered due to turbulence along the channel. Meanwhile, the dispersivity is more influenced by a large number of velocity variations in the cross-section of the underground river flow. The presence of a moving and immobile flow will increase the dispersivity value due to the drift/deflection of the solute tracer [29]. This condition is often found in the upper reaches where the bottom of the cave channel is not fully filled and in underground lakes where there is a moving and immobile flow that causes tracer substances to deviate from the flow of water carrying it.

The recovery value shows the number of tracer substances recorded at the monitoring point. The result of the calculation shows that the recovery value is $63 \%$. Of the 300 grams of uranine poured in IP1, 189.36 grams of uranine were recorded in the OP. Determination of the location of the fluorometer placement is the reason for the relatively low recovery value. This reduction is due to the existence of a PAMSIMNAS pipe installed at the top of the fluorometer placement location. With this pipe, part of the tracer substance is not recorded because it enters the pipe, thereby reducing the recovery value. This fact is reinforced by the charcoal installed in other springs around the Barat Cave which does not detect tracer substances.

\section{Conclusion}

The underground river of Barat Cave has a curvilinear branchwork pattern that starts from the Kalimas sinking stream, the Mblabak Cave, the Pendok Cave, and the Pagilangan sinking stream, then merging into a single tunnel without breaking the flow to the Barat Cave, the Pengantin Cave, and exit at Kalikarak Springs as a surface river. The transport parameter value is obtained from the Advection-Dispersion Model processing using Qtracer2 software. The transport parameter for the underground system tracing test of the Barat Cave has an advection value of $86.528 \mathrm{~m} /$ hour, a dispersion of $0.092 \mathrm{~m}^{2} / \mathrm{second}$, a dispersivity of 3.38 meters, and a recovery of $63 \%$. The transport value seems to be influenced by the characteristics of the passageway and flow conditions along the underground river. The transpor parameters value indicates slow water flow with relatively homogeneous geometric variations and the presence of an underground pool.

\section{References}

1. D.C. Ford, P.W. Williams, Karst Geomorhology and Hydrology. London: Chapman and Hall. (2007)

2. H. Karimi, Hydrogeology of Karstic Area, (2012) dalam G. A. Kazemi, Hydrogeology A Global Perspective. Croatia: In Tech (2012)
3. P. E. van Beynen, Karst management. Springer Science \& Business Media (2011)

4. E. Haryono, T. N. Adji, Geomorfologi dan Hidrologi Karst, Kelompok Studi Karst, Fakultas Geografi, Universitas Gadjah Mada (2004)

5. R. F. Agniy, A. Cahyadi, Analisis Evolusi Hidrogeokimia Airtanah di Sebagian Mataair Karst Kabupaten Rembang Bagian Selatan, in Prosiding Seminar Nasional Innovation in Environmental Management. Semarang: Program Pascasarjana Universitas Diponegoro (2015)

6. T. N. Adji, R.F. Agniy, A. Cahyadi, E. Haryono, A. Nurkholis, Karakteristik sistem aliran sungai bawah tanah di kawasan Karst Jonggrangan dengan tracer test, INA-Rxiv, 18 Sept. 2019. doi:10.31227/osf.io/9r5kh (2019)

7. A. Bogli, Karst Hydrology and Physical Speleology. Berlin: Springer-Verlag (1980)

8. Gillieson, Caves: Processes, Development, and Management. Oxford: Blackwell Publishers (1996)

9. S. B. Kusumayudha, Hidrogeologi Karst dan Geometri Fraktal Daerah Gunungsewu. Yogyakarta: Adicita Karya Nusa (2005)

10. A. Cahyadi, R. F. Agniy, Analisis Breakthrough Curve untuk Karakteristerisasi Pelorongan Di Sistem Sungai Bawah Tanah Pindul Kabupaten Gunungkidul, INA-Rxiv. August 29. doi:10.31227/osf.io/3bs2v (2017)

11. I. A. Riyanto, A. Cahyadi, T. N. Adji, E. Haryono, M. Widyastuti, R. F. Agniy, W. A. Fathon, Analisis konektivitas dan karakterisasi pelorongan dengan uji perunutan pada mataair epikarst sub-sistem panggang, kawasan karst Gunungsewu, INA-Rxiv, 2 Dec. 2018. doi:10.31227/osf.io/9d3s4 (2018)

12. A. Cahyadi, E. Haryono, T. N. Adji, M. Widyastuti, M. Naufal, F. Ramadhan, I. A. Riyanto, Analisis Konektivitas dan Karakteristik Lorong pada Sistem Hidrogeologi Mataair Beton, Kawasan Karst Gunungsewu, Kabupaten Gunungkidul dengan Uji Perunutan. Jurnal Geografi, 12(2), 105-114 (2020)

13. R. F. Agniy, A. Cahyadi, A. Nurkholis, Analisis Karakteristik Akuifer Karst dengan Uji Perunutan dan Pemetaan Gua, OSF Preprints, 2 Oct 2017 doi:10.31219/osf.io/dfxjh (2017)

14. S. Asikin, Geologi Struktur Indonesia, Bandung: ITB Press (1992)

15. Ruswanto, I. Badri, A. Anwar, Inventarisasi Geologi Lingkungan Kawasan Karst Gombong, Kabupaten Kebumen, Jawa Tengah, Laporan Proyek, Bandung: Direktorat Tata 


\section{Lingkungan Geologi dan Kawasan Pertambanagan (2002)}

16. B. D. Saputra, Morfometri Dolina di Wilayah Karst Gombong Selatan, Skripsi, Depok: Universitas Indonesia (2008)

17. R. Benischke, N. Goldscheider, C. Smart, Tracer Techniques (2007) dalam N. Goldscheider, D. Drew, Methods in Karst Hydrogeology, London: Taylor \& Francis Group (2007)

18. N. Goldscheider, J. Meiman, M. Pronk, C. Smart, Tracer tests in karst hydrogeology and speleology, International Journal of speleology, 37(1), 27-40 (2008)

19. M. S. Field, The QTRACER2 program for tracer-breakthrough curve analysis for tracer tests in karstic aquifers and other hydrologic systems, National Center for Environmental Assessment-Washington Office, Office of Research and Development, US Environmental Protection Agency (2012)

20. V. T. Tam, N. D. Trung, D. T. Ke, O. Batelaan, Interpretation of a cave system based on tracer experiment, geostructure and cave development analysis, in Trans-Karst 2004, International Transdiciplinary Conference on Development and Conservation of Karst Regions (pp. 202-206). Research Institute of Geology and Mineral Resources (RIGMR); Hanoi, Vietnam (2004)

21. E. Haryono, T. P. Sutanto, Suratman, Sutikno, Polygonal Karst Morphology of Karangbolong Area, Java-Indonesia, Acta Carsologica, 46(1) (2017)

22. C. Smart, Artificial tracer techniques for the determination of the structure of conduit aquifers, Groundwater, 26(4), 445-453 (1988)

23. A. N. Palmer, Origin and Morphology of Limestone Caves, Geological Society of America Bulletin 103, 1-21 (1991)

24. J. Jouves, S. Viseur, B. Arfib, C. Baudement, H. Camus, P. Collon, Y. Guglielmi, Speleogenesis, geometry, and topology of caves: A quantitative study of $3 D$ karst conduits, Geomorphology, 298, 86-106 (2017)

25. M. Hauns, Modeling tracer and particle transport under turbulent flow conditions in karst conduit structures, Thesis, Université de Neuchatel: Freiburger Schriften Zur Hydrologie (2000)

26. U. Lauber, W. Ufrecht, N. Goldscheider, Spatially resolved information on karst conduit flow from in-cave dye-tracing, Hydrology \& Earth System Sciences Discussions, 10(9) (2014)

27. M. Hauns, P. Y. Jeannin, O. Atteia,. Dispersion, retardation and scale effect in tracer breakthrough curves in karst conduits,
Journal of hydrology, 241(3-4), 177-193 (2001)

28. M. S. Field, A Lexicon of Cave and Karst Terminology with Special Reference to Environmental Karst Hydrology. United States Environmental Protection Agency, Washington, 214 p (2002)

29. A. Ender, N. Goeppert, N. Goldscheider, Spatial resolution of transport parameters in a subtropical karst conduit system during dry and wet seasons, Hydrogeology Journal, 26(7), 2241-2255 (2018) 